\title{
Discussion on The Trail from the Perspective of Christianism Theology
}

\author{
Jing Wang \\ Department of Chinese Language and Literature, Shandong University of Finance \\ Jinan, 250014 China
}

Tel: 86-136-7881-1209 E-mail: wangjing_sc@163.com

\begin{abstract}
Kafka is a writer of strong religious complex. In The Trail, he illustrates his religious thoughts by probing into the alienation of modern human beings from the God and also shows his pursuit and befuddlement of beliefs. This paper analyzes the crimes and punishment in The Trail through three parts, the accusation of crime, the understanding of crime and the pleading of crime.
\end{abstract}

Keywords: Kafka, The Trail, Christianism

Kafka is a representative writer among writers of modern western novels. His long novel, The Trail, was called "the greatest works" by Brod, the editor of Kafka's works.

The Trail tells the story of Joseph K., who was accused of a crime he did not commit and was sentenced to death. If we judge this novel from mundane perspective, there is no way to explain why Joseph L. was accused of crime while being innocent. It seems that the story was absurd. However, if we understand this novel based on the theology thoughts of Christianism, the process lasting from K.'s being accused to K.'s pleading of crime shows the author's disquiet and thoughts about the living state, the absence of belief and the redemption of souls of modern human beings.

\section{The crime of non-commitment of crime: the alienation of human beings and from the God}

The Trail describes the experience of Joseph K., a senior bank worker. He is a successful junior manager of a bank and always follows the direction of law. On one fine morning, he was suddenly informed that he had committed crime. He received the writ of summons from the court and was required to attend the court for trail. What is stranger, the court did not announce what crime he committed and did not deprive him of freedom of movement. K. was furious about the act of the court. At the court hearing, he denunciated the corruptness of the law institutes and the judges' embezzlement of public property. He decided to pay no mind to this case. However, the increasing psychological pressure on him made him unable to eat and sleep well. He started to hate working. He put his attention to the case and visited lots of people and places for the case.

The writing style of The Trail is the incarnation of Kafka style. The seemingly absurd story contains deep thoughts. As is well known, in the works of Kafka, the Jewish culture and religious thoughts play significant roles. As remarked by critics, "if we do not take into account the explanation based on the modern thoughts, we will find that it is better to recognize that the works of Kafka is more closely connected with Bible Job than to include them into 'modern literature'. His works are based on religion, especially Jewish consciousness. It is meaningless to analyze Kafka's works from other perspectives" (Murray, 2006). Starting from this understanding, when reviewing the absurd description of The Trail, it will be easy to find the Christianism thoughts deeply contained in it.

In modern society, Nietzsche alleged that the God was dead. The belief of the westerners towards the God collapsed suddenly. They themselves become the God for themselves. They are self-centered, do as they like to meet their desires and even lapse from virtue. They alienate themselves from the God, discard their beliefs, are addicted to material desires and descend to earthliness. This is the common living state of modern human beings and is the crime that human beings have committed by breaching their agreements with the God. I am not, but the God is. In other words, from the time of birth, I place myself as the God. This is my original sin (Xu, 2006).

Besides, the theology thought of Christianism explains the "crime' in another way. The "crime" is "the damage of the glory of the God". Paul alleged that all human beings had committed crimes and damaged the glory of the God. Many of us will be confused at this sentence. Most of people on the earth abide by laws in their whole life and have never contravened the regulations and laws and entered into the court, never to mention committed severe crimes, such as killing people. How could they all commit crimes and damage the glory of the God (Xu, 2006)? This sentence just describes what $\mathrm{K}$ faces. From the mundane perspective, $\mathrm{K}$. did not commit crime. Even, we can say that $\mathrm{K}$ is a 
successful man. However, in the theology thoughts of Christianism, the pride that human beings take in theirs knowledge, capacity and morality is a kind of crime.

In The Trail, Kafka fully illustrates the crimes of human beings when facing the God by describing reality. Human beings alienate themselves from the God but still feel that they are innocent. Like K., they defend for themselves with confidence. He attended the court to explain and defend for himself. He found lawyers to get clear understanding of the case. The activities illustrated in the novel reveal various phenomenons in real world. The random description of the seemingly trivial events reflects the nature of the social reality. It is those trivial events that cause the alienation of human beings from the God and their betrayal of the God.

"How does crime enter into this world? Human beings should find the answer themselves; if he or she wants to know the reason from others, the understanding will be erroneous" $(\mathrm{Xu}, 2006)$. Therefore, Kafka let the characters in his novel face their real selfs so as to understand the crimes they have committed, just like K. in The Trail who fully devoted to the reasoning of the case. This is a process he understands the crime and is also a chance for him to get away from the earthliness and return to the spirit.

\section{The road of understanding the crimes: the lamb of the God, who lost way but found the way back}

At the beginning, K. just let alone the case. Afterwards, he focused his attention on the case and gradually entered into the understanding of crimes. The lawyer he employed comprised with the court and delayed the case. He was irritated and left for others.

He then went to visit a painter and was advised that once the court filed the lawsuit, he was ascertained to be guilty and no law could ever change it. However, there is possibility of being acquitted, including real acquittal, release on parole, and the postponement of trail. The release on parole and the postponement of trail could only bring him temporary freedom. The ideal way is to get acquittal. However, no one on the earth could ever get it. What is more, the painter told $\mathrm{K}$ that even judges of highest rank on the earth was low-classed. They were not entitled to rule someone to be acquitted; only the highest court could. But, no one, including you, I and others, could get close to that court. In this connection, it can be told that the highest court described by Kafka does not belong to the earth; rather, the highest court refers to the God that the common people could hardly know well. Only the God can adjudicate whether a human is guilty or not. By this way, Kafka let $\mathrm{K}$. gradually realize the existence and the power of the God.

Then, K. met the merchant Bullock who was also involved in a case. The merchant told $\mathrm{K}$ that a person involved in a case would be exhausted at last and could do nothing. K. did not want to be like him. Hence, K fired his lawyer and got himself out of the mundane trail. K., after giving up the mundane defense, shouldered his own life and went to search for the destination of his life.

At last, K. came to a big church. At the place where human beings communicated with the God, K. met a priest. There he listened to the story, "in front of the door of law", told by the priest. He was told that there was law. However, the road leading to the law was blocked and hard to achieve.

The characteristic of modern society alienates human beings from the God and their spiritual beliefs. Like spiritual wanderers, they are waddling lonely on the wold. They are searching for the direction of their lives and will not quit no matter how hard it is. In The Trail, K. gradually realized his crimes in the process of searching and asking.

This is a process of understanding crimes. K. gradually became aware of the distortion of the relationship between the God and him and tried to adjust the relationship. "The most basic nature of crime is breach of contract and is the damage of the relationship between the God and human beings by contravening commandments" (Xu, 2006). K., living in the modern world, just had an obscure memory of the God and even forgot his agreement with the God. Every day, he was engaged in the real materials and neglected the pursuit of spiritual world and the communication with the God, which is just the crime he committed. Actually, K. represents modern human beings. Every person lives under the state as K. did. Kafka, just like a prophet, predicted the helplessness of modern human beings in their lives and reminded human beings who committed the crimes to find their way back. The search process of K. warns human beings to acknowledge their faults and follow their beliefs.

The existence of human beings is not just to deal with the exterior objective reality. What is more importance for the existence of human beings is the individual spiritual life. In the process of human beings' understanding of crimes, they communicate with the God again, realize their crimes, and re-understand life and existence. However, after understanding crimes, where can human beings already addicted into crimes go? Will the redemption of the God come again?

\section{The death of pleading of crime: the voyage of redemption of souls of modern human beings}

In the process for clarifying facts and fighting for himself, K. gradually realized his crimes. The story told by the priest wakened K. Afterwards, his attitude towards the reality totally changed. At the end of the novel, Kafka described the 
sentence of K.. K. did not resist. Even, K. coordinated the two Jack Ketches to sentence him. Kafka let K. accept death with a peaceful and obedient mood.

Such description contradicts with the initial description of K., rebelling against the court. Why there is such difference? What makes K. face death so peacefully? "One piece of evidence for the popularity of crimes is that every people shall face the consequence of crime, that is, death. Maybe human beings would not like to admit that every one has committed crime; however, every one has to admit and cannot escape from death. It has been stated in the Bible that death is the consequence of crime" (Xu, 2006).

Before the God, the end of guilty people is death. After experiencing the accusation of crime and the understanding of crime, K. clearly understood the existence process of human life and realized that death was the end for every one. After encountered failure for several times when searching for helps from others, $\mathrm{K}$. was led to a big church and communicated with the priest there. He was told by the priest the story named "in front of the door of law". There are two characters in the story. One is the gatekeeper guarding in front of the door of law and the other is a farmer who wants to go into the door of law and is kept out of the door. The gatekeeper enlightens the farmer that he could go through the door but has to wait for the right moment. Therefore, the farmer devotionally waits outside the door till the coming of the end of his life. Just at the end of his life, he sees a light endlessly radiating from the door of law. Maybe the light is the redemption light. In the church, K. also saw a silvery holy picture flashing with silvery light in from of his eyes.

The priest told $\mathrm{K}$. that he belonged to the court, but had no requirement on K.. He said, "The court does not place any requirement on you. If you come, the court will take you. If you leave, the court will let you go" (Kafka, 2003). At that moment, the priest is just like the gatekeeper, while K. the farmer. The law is the God. Human beings are free. If they believe in God, they can come. If not, they can leave as they want. The God calls for human beings, however do not force them. Human beings can make choice freely. If they believe in God, they will have belief. If not, they will wonder on the earth. At that moment, K. had already been attracted by the speech of the priest. Although he said that he should leave the church and go back to the bank, he still approached the priest. "Just because the symbols of belief strive out of extreme suspicion, through the examination and clarifying, their trueness is valuable and fierce. 'Human beings cannot live without everlasting belief on an unbeatable thing"'(Brod, 1997). K. experienced a tortuous process for his re-communication with the God. However, can he be saved after believing in the God? Kafka is not sure either.

Max Brod, good friend of Kafka, believed that from the aspect of religious thoughts, Kafka shall be categorized as "crisis theology". "The trend of such theology is that between the God and human beings and between human beings and the virtuous acts generated by the power of human beings, there lies a gab than can never be filled" (Brod, 1997). It is this gad that makes the end of The Trail obscure. K. acknowledged crime, understood the alienation of human beings from the God and realized the importance of belief on the life of human beings. However, the modern human beings can never reach the former relationship with the God. K, grasping the slim hope to be saved, chose death without any rebelling.

"Every great litterateur always can clearly demonstrate certain things in life that no one can see clearly before him. Then, what is made clear by Kafka? It should be the unclearness of life" (Brod, 1997). In The Trial, Kafka shows people the chaos of modern life, especially the spiritual life. It is the alienation from the God that caused the absence of belief. He shows modern people their own living state, and points out the direction of the beginning of a new life. But he also points out the unclearness of life. He was unsure about the resumption of the relationship between human and God. He did not know whether the soul of human could be saved finally. So, K. died with helpless compromise. It is still a question that where is the destination of the soul of human. No one knows that when we can get a satisfactory answer.

At the end of the novel, Kafka stills leaves a slime hope for readers. Before K. was put to death, his eyes rest on the top of a house beyond the stone filed. He saw a flashing of light. Then, one window of the house opened and one man suddenly leaned out of the window. $\mathrm{K}$ was thinking: who is that? A friend? A good man? A man with sympathy? A man who is willing to help others? Just one man or all the men? Can we be saved? Are there cases that were forgotten to be appealed? There must be such cases. Logic is unshakable, but it cannot stop a man with hope of living from holding hopes. Where is the judge he had never seen? Where is the highest court that he failed to enter into? He raised his hands and stretched his ten figures ......

Where is the God? Who will save the human beings on the earth with sins? How long will the punishment that put human beings wonder lonely in the voyage of redemption last? Kafka used a series of question marks to let L. cry that the human beings living in the modern spiritual wold are waiting for the coming of being saved.

\section{References}

Brod, Max. (1997). The Bibliography of Kafka. Translated by Ye, Yanfang. Shijiazhuang: Hebei Education Press. P.174, 172, 175. 
Kafka. (2003). Kafka Works. Translated by Han, Ruixiang. Beijing: People's Literature Press. P.355.

Murray, Nicholas. (2006). Kafka. Translated by Zheng, Haijuan. Beijing: International Culture Press Company. P.91.

Xu, Zhiwei. (2006). A Guide of the Christianism Theology Thoughts. Beijing: China Social Science Press. Pp.145, 146, 148, 161. 